\title{
Assessment of Protective Effects of Methanolic Extract of Salvia verbenaca Roots Against Oxidative Damage Induced by Hydrogen Peroxide
}

\section{Hidrojen Peroksitin Neden Olduğu Oksidatif Hasara Karşı Salvia verbenaca Köklerinin Metanol Ekstresinin Koruyucu Etkilerinin Değerlendirilmesi}

\author{
(D) Meryem NASSAR*, (D) Fethia ZADRI, (D) Souheila SLIMANI \\ University of 20 Aout 1955, Department of Natural Science and Life, Skikda, Algeria
}

\begin{abstract}
Objectives: Salvia verbenaca is a medicinal plant that has been traditionally used in Algeria for the treatment of wounds and emptied abscesses. The present study aimed to evaluate the cytotoxicity of methanolic extract of $S$. verbenaca roots and explore its ability to bestow protection against oxidative damage induced by $\mathrm{H}_{2} \mathrm{O}_{2}(200 \mu \mathrm{M})$.

Materials and Methods: The cytotoxic effects and protective properties of S. verbenaca on human monocytic leukemia cells (THP-1) was studied using thiazolyl blue tetrazolium bromide assay. The protective effects of the extract against $\mathrm{H}_{2} \mathrm{O}_{2}$-induced oxidative damage was evaluated using single cell gel electrophoresis (comet) assay and 2,7-dichlorodihydrofluorescien diacetate (H2DCFDA) assay.

Results: S. verbenaca extract was found to be non-cytotoxic at concentrations $\langle 500 \mu \mathrm{g} / \mathrm{mL}$. However, the use of 500 and $1000 \mu \mathrm{g} / \mathrm{mL}$ of the extract decreasedcell viability. H2DCFDA assay provided evidence for anti-oxidative properties of S. verbenaca. Addition of S. verbenaca (1 and $10 \mu \mathrm{gg} /$ $\mathrm{mL}$ ) resulted in significant reductionin $\mathrm{H}_{2} \mathrm{O}_{2}$-induced reactive oxygen species (ROS) production. Further, comet assay showed that addition of the extract resulted in a significant reductionin the length and \% DNA content of comet tail. Additionally,nuclei in the cells also appeared to be devoid ofdegradation.
\end{abstract}

Conclusion: The use of $\mathrm{S}$. verbenaca root extract conferred protection against $\mathrm{H}_{2} \mathrm{O}_{2}$-induced ROS production and DNA breakage in vitro.

Key words: Salvia verbenaca root, THP-1 cells, reactive oxygen specices production, comet assay

ÖZ

Amaç: Salvia verbenaca, Cezayir'de geleneksel olarak yaraların ve boşalan apselerin tedavisinde kullanılan tıbbi bir bitkidir. Bu çalışma, S. verbenaca köklerinin metanol ekstresinin sitotoksisitesini değerlendirmeyi ve $\mathrm{H}_{2} \mathrm{O}_{2}(200 \mu \mathrm{M})$ ile indüklenen oksidatif hasara karşı koruyucu etkisini araştırmayı amaçlamaktadır.

Gereç ve Yöntemler: S. verbenaca'nın insan monositik lösemi hücrelerindeki (THP-1) sitotoksik etkileri ve koruyucu özellikleri tiyazolil mavi tetrazolyum bromür testi ile belirlendi. Ekstrenin $\mathrm{H}_{2} \mathrm{O}_{2}$ kaynaklı oksidatif hasara karşı koruyucu etkileri, tek hücre jel elektroforezi (comet) testi ve 2,7-diklorodihidroflorescien diasetat (H2DCFDA testi) kullanılarak değerlendirildi.

Bulgular: S. verbenaca ekstresinin $\langle 500 \mu \mathrm{g} / \mathrm{mL}$ konsantrasyonlarında sitotoksik olmadığı bulundu. Bununla birlikte, $500 \mathrm{ve} 1000 \mu \mathrm{g} / \mathrm{mL}$ ekstrenin

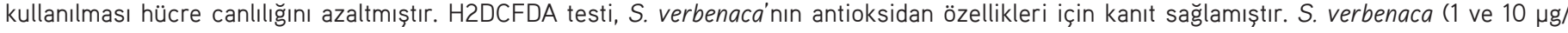
$\mathrm{mL}$ ) ilavesi, $\mathrm{H}_{2} \mathrm{O}_{2}$ ile indüklenen reaktif oksijen türlerinin (ROS) üretiminde önemli derecede azalma ile sonuçlandı. Ayrıca, comet analizi, ekstrenin eklenmesinin comet kuyruğunun uzunluğunda ve \% DNA içeriğinde önemli bir azalmaya neden olduğunu gösterdi. Ek olarak, hücredeki çekirdeklerde degradasyon olmadığı görüldü.

Sonuç: S. verbenaca kökü ekstresinin kullanılması, in vitro olarak $\mathrm{H}_{2} \mathrm{O}_{2}$ kaynaklı ROS üretimine ve DNA kırılmasına karşı koruma sağladı. Anahtar kelimeler: Salvia verbenaca kökü, THP-1 hücreleri, reaktif oksijen türlerinin üretimi, comet testi 


\section{INTRODUCTION}

Plants of the Salvia genus are widely known for their applications in food, cosmetics, and pharmaceutical industries.' Salvia is the largest genus of the Lamiaceae family with 1000 species distributed all across the globe, particularly in the Mediterranean basin, SouthEast Asia, and Central and South America. ${ }^{2}$ Essential oils and concentrates from Salvia species are endowed with numerous therapeutic properties, including antimicrobial, hypoglycemic, antiphlogistic, antituberculous, and antiinflammatory properties. The use of these oils also aids in cancer prevention. ${ }^{3-5}$ In Algeria, 18 species of Salvia genus are known. Among these, Salvia verbenaca, commonly known as Meryiamia or khiyata, is used in combination with other medicinal herbs to treat cold. ${ }^{6}$ Flowering leaves and tops of this plant exhibit stomachic, stimulating, ${ }^{7}$ tonic, vulnerary, and antirheumatic effects. ${ }^{8}$

S. verbenaca is used to prepare tonics and stimulating infusions. ${ }^{9}$ Freshly chopped leaves of this plant are applied as a poultice on the infected wounds and emptied abscesses to facilitate healing. ${ }^{10}$

Oxidative stress is generally induced by the generation of reactive oxygen species (ROS), which principally react with proteins, lipids, and DNA." ROS are known to promote decrease in glutathione (GSH), changes in hormones, oxidative DNA damage, genetic transformation, DNA chain rupture, and chromosomal modifications. ${ }^{12}$

Oxidative damage to DNA poses a serious problem as DNA cannot be resynthesized or corrected. ROS mainly include free radicals like hydroxyl radicals $\left({ }^{\circ} \mathrm{OH}\right)$, superoxide anions $\left(\mathrm{O}_{2}{ }^{-}\right)$and non-radical molecules like hydrogen peroxide $\left(\mathrm{H}_{2} \mathrm{O}_{2}\right)$. Primarily, ROS are generated from oxidative metabolism in mitochondria. The other endogenous sources of ROS include inflammatory cells and peroxisomes. ${ }^{13}$ ROS can attach easily to DNA, which is mainly mediated via higher reactivity of ROS with strong nucleophilic sites present on nucleobases. Various mutations, like base alterations or base adhesion, can be produced via interaction of mutagenic agents with DNA bases or deoxyribose sugar. ${ }^{14}$ Moreover, oxidative damage to DNA might induce mutations, resulting in activation of oncogenes or inactivation of tumor suppressor genes as well as alterations in gene expression. ${ }^{15}$

Several studies have explored the biological activity of the aerial parts of Salvia species. The present study aimed to evaluate biological activities of $S$. verbenaca root extract. This is the first report for in vitro evaluation of cytotoxic and protective effects of the methanolic extract of $S$. verbenaca roots against $\mathrm{H}_{2} \mathrm{O}_{2}-$ induced oxidative stress.

\section{MATERIAL AND METHODS}

\section{Salvia verbenaca as plant sample}

S. verbenaca plants were collected from Oued Abid-Batna. The roots of the plants were dried for 15 days at room temperature and converted into fine powder using a blender.

\section{Extraction}

For extraction, $100 \mathrm{mg}$ of powdered roots were macerated in a hydroalcoholic mixture $\left(\mathrm{MeOH}: \mathrm{H}_{2} \mathrm{O}, 7: 3 \mathrm{v} / \mathrm{v}\right)$ for $24 \mathrm{~h}$. The extraction process was repeated twice. The hydroalcoholic extracts were mixed and concentrated using a rotary vacuum evaporator. The crude extract was weighed and stored at $4^{\circ} \mathrm{C}$ until further use. ${ }^{16}$

\section{Cell culture}

Human monocytic leukemia cell line THP-1 (Rockville, MD, USA) was grown in RPMI-1640 medium supplemented with 10\% (v/v) fetal bovine serum, $2 \mathrm{mM}$ L-glutamine, $1 \mathrm{mM}$ sodium pyruvate, $50 \mu \mathrm{g} / \mathrm{mL}$ streptomycin, and $50 \mathrm{U} / \mathrm{mL}$ penicillin (Sigma, Milan, Italy). The cells were cultured in $\mathrm{T} 75$ flasks at cell density of $5 \times 10^{5}$ cells $/ \mathrm{mL}$ and maintained at $37^{\circ} \mathrm{C}$ in a humidified chamber under $5 \% \mathrm{CO}_{2}$.

For assay, THP-1 cells were seeded in 24- or 96-well plates and treated with $\mathrm{H}_{2} \mathrm{O}_{2}(200 \mu \mathrm{M})$ for $24 \mathrm{~h}$ either alone or in the presence of the extract. The extracts were added to the culture medium 30 mins prior to the addition of $\mathrm{H}_{2} \mathrm{O}_{2}$. Stock solution (50 $\mathrm{mg} / \mathrm{mL}$ ) of the extract was prepared by dissolving extract in dimethyl sulfoxide (DMSO) (1\%).

\section{Evaluation of cytotoxicity of plant extract}

To evaluate the cytotoxic effects of $S$. verbenaca, THP-1 cells were treated with six concentrations of the extract $(1,10,50$, 100,500 , and $1000 \mu \mathrm{g} / \mathrm{mL}$ ) and cytotoxicity was measured using 3-(4,5-dimethylthiazol-2yl)-2,5-diphenyltetrazolium bromide (MTT) assay. Generally, MTT assay involves conversion of yellow tetrazolium salt to purple formazan crystals in viable cells by the action of $\mathrm{NAD}(\mathrm{P}) \mathrm{H}$-dependent oxidoreductase enzymes. The resulting insoluble formazan crystals are dissolved using DMSO and cell viability/proliferation is measured in terms of absorbance of purple colored solution at $570 \mathrm{~nm}$.

The concentration at which the root extract was non-cytotoxicity was identified and used for further studies. To evaluate the protective effects of $S$. verbenaca, THP-1 cells were seeded in a 96-well plate at a cell density of $5 \times 10^{4}$ cells $/ \mathrm{mL}$ and treated with $\mathrm{H}_{2} \mathrm{O}_{2}(200 \mu \mathrm{M})$ for $24 \mathrm{~h}$ both in the presence and absence of the extract. Further, the cells were washed with phosphate buffer solution (PBS), transferred intoa fresh 96-well plate, and incubated with MTT $(0.5 \mathrm{mg} / \mathrm{mL})$ for $4 \mathrm{~h}$ at $37^{\circ} \mathrm{C}$. The formazan crystals were dissolved using100 $\mu \mathrm{L}$ of acidic isopropanol (0.04 $\mathrm{M} \mathrm{HCl}$ in absolute isopropanol) and the cells were incubated for $1 \mathrm{~h} .{ }^{17}$ The absorbance of the samples was measured at $540 \mathrm{~nm}$ using a microplate spectrophotometer (Tecan Italia, ColognoMonzese, Italy). The cell viability (\%) was estimated using the formula, [(absorbance of treated cells/absorbance of untreated cells) $\times 100$ ]. The experiment was performedin triplicates, with three wells per treatment $(n=9)$.

\section{Evaluation of ROS production}

The production of ROS was evaluated using 2',7'-dichlorodihydrofluorescein diacetate (H2DCFDA) a nonfluorescent probe which crosses the plasma membrane before being cleaved into DCFH by intracellular esterases. DCFH can then be oxidized to fluorescent DCF by ROS. 
In a 12-well plate, the cells were seeded at a density of $5 \times 10^{5}$ cells $/ \mathrm{mL}$ and treated with $S$. verbenaca extract (1 and $10 \mu \mathrm{g} /$ $\mathrm{mL}$ ), both in the presence and absence of $\mathrm{H}_{2} \mathrm{O}_{2}$. The cells were incubated for $24 \mathrm{~h}$ at $37^{\circ} \mathrm{C}$. After $24 \mathrm{~h}$, the cells were washed twice with PBS and ROS production was estimated using H2DCFDA $(5 \mu \mathrm{M})$. The cells were incubated at $37^{\circ} \mathrm{C}$ for $30 \mathrm{~min}$ in a humidified incubator under $5 \% \mathrm{CO}_{2}$. Following this, the cells were suspended again in $200 \mathrm{~mL}$ PBS containing $0.1 \mathrm{M}$ $\mathrm{K}_{2} \mathrm{PO}_{4}$ and $0.5 \%$ Triton $\mathrm{X}-100$. The samples were transferred into a 96-well plate with transparent bottom. ${ }^{18}$ The oxidation of H2DCFDA was estimated in terms of fluorescence using a microplate reader, with excitation-emission filters fixed at 485 and $480 \mathrm{~nm}$, respectively. The amount of ROS produced was expressed in term of percentage of fluorescence intensity of THP-1 cells. The experiment was performed in triplicates, with three wells per treatment $(n=9)$.

\section{Evaluation of DNA breakage}

$\mathrm{H}_{2} \mathrm{O}_{2}$-induced DNA breakage was assessed using comet assay, according to the protocol described by Di Pietro et al. ${ }^{19}$ The comet assay works on the principle that undamaged DNA migrates in the gel at a slow rate and remains within the confines of the nucleoid when current is applied. Thus, it appears as an intact comet head. In comparison to this, the broken DNA migrates at a faster rate and forms a comet-like tail. The fluorescent intensity and shape of this tail can be used to measure level of damage. ${ }^{20}$ DNA breakage can be quantified by measuring the length and \% DNA in the tail of each comet. In a 96-well plate, THP-1 cells were seeded at a density of $5 \times 10^{4}$ cells $/ \mathrm{mL}$ and treated with $S$. verbenaca extract with and without $\mathrm{H}_{2} \mathrm{O}_{2}$. After $24 \mathrm{~h}$, the cells were washed twice with PBS. Following this, the cells were mixed with $0.5 \%$ low melting point agarose at $37^{\circ} \mathrm{C}$ to achieve a concentration of $10 \times 10^{4}$ cells $/ \mathrm{mL}$. Further, $50 \mu \mathrm{L}$ of this cell suspension was loaded on to pre-coated glass slides and immediately covered with covers slips. These slides were incubated at $4^{\circ} \mathrm{C}$ for $15 \mathrm{~min}$. Further, the covers slips were carefully removed and additional $50 \mu \mathrm{L}$ of low melting agarose $(0.5 \%)$ was added onto the previously coated cell layer. The samples were allowed to solidify in ice surface for $5 \mathrm{~min}$. The slides were immersed into lysis solution (100 mM EDTA, 2.5 M $\mathrm{NaCl}, 10 \mathrm{mM}$ Tris, $1 \%$ Triton $\mathrm{X}-100, \mathrm{pH} \mathrm{10,4}{ }^{\circ} \mathrm{C}$ ) for 1 h. Further, the slides were incubated in an electrophoresis solution $(10 \mathrm{~N}$ $\mathrm{NaOH}, 200 \mathrm{mM}$ EDTA, $\mathrm{pH}>13$ ) for 20 min to ensure unwinding of DNA. Post winding, the DNA was subjected to electrophoresis in a similar buffer for $30 \mathrm{~min}(25 \mathrm{~V}, 300 \mathrm{~mA})$.

After electrophoresis, the slides were washed with neutralization buffer $(0.4 \mathrm{M}$ Tris, $\mathrm{pH} 7.5)$, three times for 5 min each. The slides were stained with ethidium bromide and analyzed at 10x40 magnification using an epifluorescence microscope DM IRB (Leica Microsystem, Heidelberg, Mannheim, Germany) with an integrated digital camera (Canon Power Shot S50, Milan, Italy).

\section{Statistical analyses}

All statistical analyses were performed using One-Way ANOVA. The difference between the means of the group was analyzed by Tukey's post-hoc test using SPSS software. The results were reported as the mean \pm standard error and the analysis was considered significant for $p<0.05$.

\section{RESULTS}

\section{Cytotoxicity}

MTT assay was used to evaluate the cytotoxic effects of six concentrations of $S$. verbenaca root extract. As shown in Figure 1, the treatment of THP-1 cells with $200 \mu \mathrm{M}$ of $\mathrm{H}_{2} \mathrm{O}_{2}$ resulted in a significant reduction in cell viability ( $p<0.05)$. After $24 \mathrm{~h}$ of treatment with $\mathrm{H}_{2} \mathrm{O}_{2}(200 \mu \mathrm{M})$, only $67 \%$ of the cells were viable. For $S$. verbenaca extract, four concentrations (1, 10, 50 and $100 \mu \mathrm{g} / \mathrm{mL}$ ) did not show any significant cytotoxicity. However, use of 500 and $1000 \mu \mathrm{g} / \mathrm{mL}$ of the extract resulted in a significant decrease in cell viability. S. verbenaca extract at $1000 \mu \mathrm{g} / \mathrm{mL}$ concentration resulted in $70 \%$ cell death $(p<0.001)$. Thus, S. verbenaca was found to be safe at doses $\leq 100 \mu \mathrm{g} / \mathrm{mL}$.

\section{Production of ROS}

$\mathrm{H}_{2} \mathrm{O}_{2}$-induced oxidative stress was evaluated in terms of intracellular levels of ROS, assessed using H2DCFDA assay. As shown in Figure 2 the treatment of THP-1 cells with $\mathrm{H}_{2} \mathrm{O}_{2}$ $(200 \mu \mathrm{M})$ alone promoted the production of ROS ( $p<0.001)$. To evaluate the antioxidative effect of $S$. verbenaca extract, the cells were treated with 1 and $10 \mu \mathrm{g} / \mathrm{mL}$ of the extract along with $\mathrm{H}_{2} \mathrm{O}_{2}$. The presence of the extract resulted in a significant reduction in the intracellular levels of ROS as compared to the cells treated with $\mathrm{H}_{2} \mathrm{O}_{2}$ alone. The protective effect of the root extract was found to be more pronounced at the concentration of $10 \mu \mathrm{g} / \mathrm{mL}$. The use of $S$. verbenaca extract alone did not show any augmentation in the intracellular ROS levels (Figure 2).

\section{DNA breakage}

Comet assay was used to evaluate $\mathrm{H}_{2} \mathrm{O}_{2}$-induced DNA breakage as well as the ability of $S$. verbenaca extract to protect THP-1 cells against this DNA damage (Figure 3). DNA damage was measured in terms of the amount of DNA present in the comet head and tail. As shown in Figure 3, the treatment of THP-1 cells with $\mathrm{H}_{2} \mathrm{O}_{2}$ for $24 \mathrm{~h}$ resulted in a significant increase in DNA

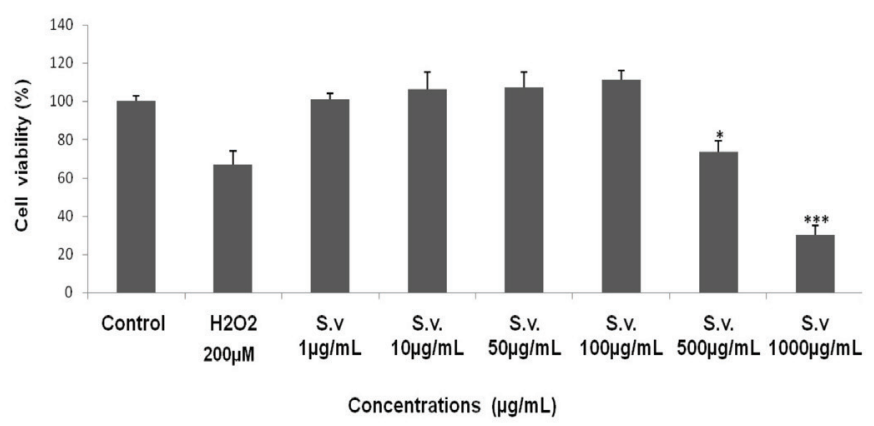

Figure 1. Effect of methanolic extract obtained from Salvia verbenaca roots (S.v) on the cell viability of THP-1 cells studied using MTT assay. No cytotoxic effects were observed for the root extractat concentrations $<500$ $\mu \mathrm{g} / \mathrm{mL}$, however, higher concentrations (500 and $1000 \mu \mathrm{g} / \mathrm{mL}$ ) of the extract resulted in significant cytotoxicity. Data presented as mean $\pm \mathrm{SE}$ $(n=9) .{ }^{*} p<0.05$ and ${ }^{* * *} p<0.001$ compared tocontrol cells

MTT: 3-(4,5-dimethylthiazol-2yl)-2,5-diphenyltetrazolium bromide, SE: Standard error 
breakage ( $p$ <0.001). As expected, THP-1 cells treated only with S. verbenaca root extract ( 1 and $10 \mu \mathrm{g} / \mathrm{mL}$ ) did not promote any increase in the comet parameters ( $p>0.05)$. These cells showed no significant changes in the length and \% DNA ofthe tail as compared to the control.

Interestingly, $S$. verbenaca resulted in a significant $(p<0.001)$ and dose-dependent reduction in DNA breakage induced by $\mathrm{H}_{2} \mathrm{O}_{2}$ in THP-1 cells.

THP-1 cells treated with $\mathrm{H}_{2} \mathrm{O}_{2}$ alone were characterized by fragmented head and apparent tail (comet aspect). However, treatment of the cells with the extract ( 1 and $10 \mu \mathrm{g} / \mathrm{mL}$ ) resulted in lower fragmentation and the cells displayed a spherical aspect. Thus, S. verbenaca root extract exhibited ability to protect THP-1 cells against DNA breakage induced by $\mathrm{H}_{2} \mathrm{O}_{2}$ (Figure 4).

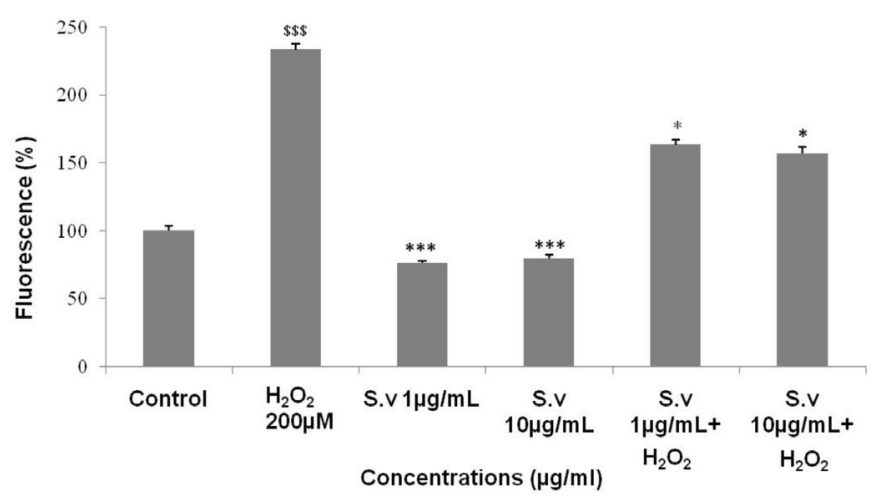

Figure 2. Effect of methanolic extract of Salvia verbenaca roots (S.v) on the intracellular levels of ROS induced by $\mathrm{H}_{2} \mathrm{O}_{2}$ in THP-1 cells studied using H2DCFDA assay. THP- 1 cells $\left(5 \times 10^{5}\right.$ cells $/ \mathrm{mL} / 12$-well plate $)$ were incubated with $\mathrm{S}$. verbenaca (1 and $10 \mu \mathrm{g} / \mathrm{mL}$ ) with or without $\mathrm{H}_{2} \mathrm{O}_{2}(200 \mu \mathrm{M})$ for $24 \mathrm{~h}$. Data presented as mean $\pm \mathrm{SE}(n=9)$. ${ }^{\$ \$} \mathrm{p}<0.001, \mathrm{H}_{2} \mathrm{O}_{2}$ compared to control, ${ }^{* * *} p<0.001$ and ${ }^{*} p<0.05 \mathrm{~S}$. verbenaca treated groups compared to $\mathrm{H}_{2} \mathrm{O}_{2}$ ROS: Reactive oxygen species, H2DCFDA: 2,7-dichlorodihydrofluorescien diacetate, SE: Standard error

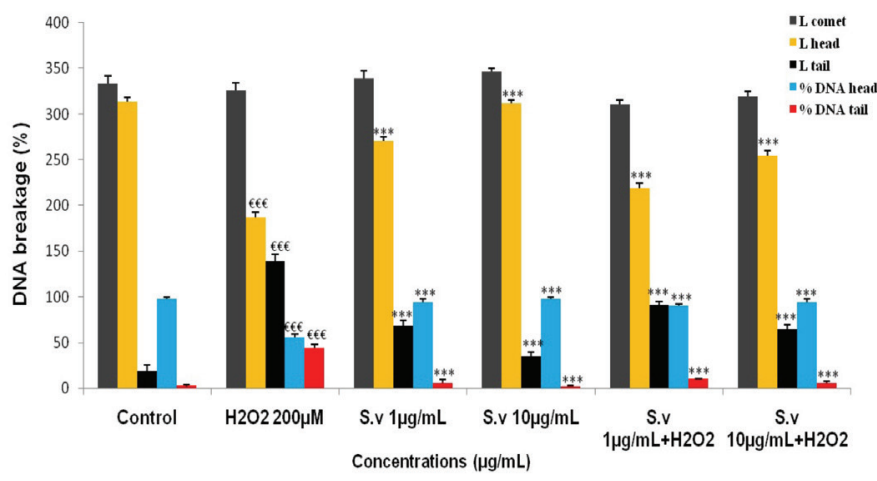

Figure 3. Effect of methanolic extract of Salvia verbenaca roots (S.v) on the level of DNA damage induced by $\mathrm{H}_{2} \mathrm{O}_{2}$ in THP-1 cells studied using comet assay. THP-1 cells $\left(5 \times 10^{4}\right.$ cells $\left./ \mathrm{mL}\right)$ were incubated with S. verbenaca (1 and $10 \mu \mathrm{g} / \mathrm{mL}$ ) with or without $\mathrm{H}_{2} \mathrm{O}_{2}(200 \mu \mathrm{M})$ for $24 \mathrm{~h}$. DNA damage was expressed in terms of \% of DNA content in comet head and tail. Data presented as mean $\pm \mathrm{SE}(n>50)$. ${ }^{\$ \$}{ }^{\$} \mathrm{p}\left\langle 0.001, \mathrm{H}_{2} \mathrm{O}_{2}\right.$ compared to control, ${ }^{* * *} p<0.001$ and ${ }^{*} p<0.05 \mathrm{~S}$. verbenaca treated groups compared to $\mathrm{H}_{2} \mathrm{O}_{2}$

SE: Standard error

\section{DISCUSSION}

The present study aimed toevaluate the ability of $S$. verbenaca root extract to ameliorate $\mathrm{H}_{2} \mathrm{O}_{2}$-induced $\mathrm{ROS}$ generation and DNA breakage. To establish the protective effects of the extract, THP-1 cells were incubated with 1 and $10 \mu \mathrm{g} / \mathrm{mL}$ of the extract for 24 h. S. verbenaca extract (at concentrations $<500 \mu \mathrm{g} / \mathrm{mL}$ ) was found to non-cytotoxic and promoted cell growth, as indicated by cell viability of $>100 \%$. Interestingly, S. verbenaca at concentrations $>500 \mu \mathrm{g} / \mathrm{mL}$ was found to be more cytotoxic as compared to $\mathrm{H}_{2} \mathrm{O}_{2}$. In fact, the use of $1000 \mu \mathrm{g} / \mathrm{mL}$ of the extract resulted in $30 \%$ viability. Thus, all these results indicated anticancerous activity of higher doses of S. verbenaca toward THP-1 cells. Several previous studies have reported cytotoxic effects of various Salvia species, however, the concentration at which these extracts exert cytotoxic effects is species dependent.

Poyraz et al. ${ }^{21}$ evaluated the cytotoxic activities of S. aethiopis L. and S. ceratophylla L. in mouse embryonic fibroblast cell line
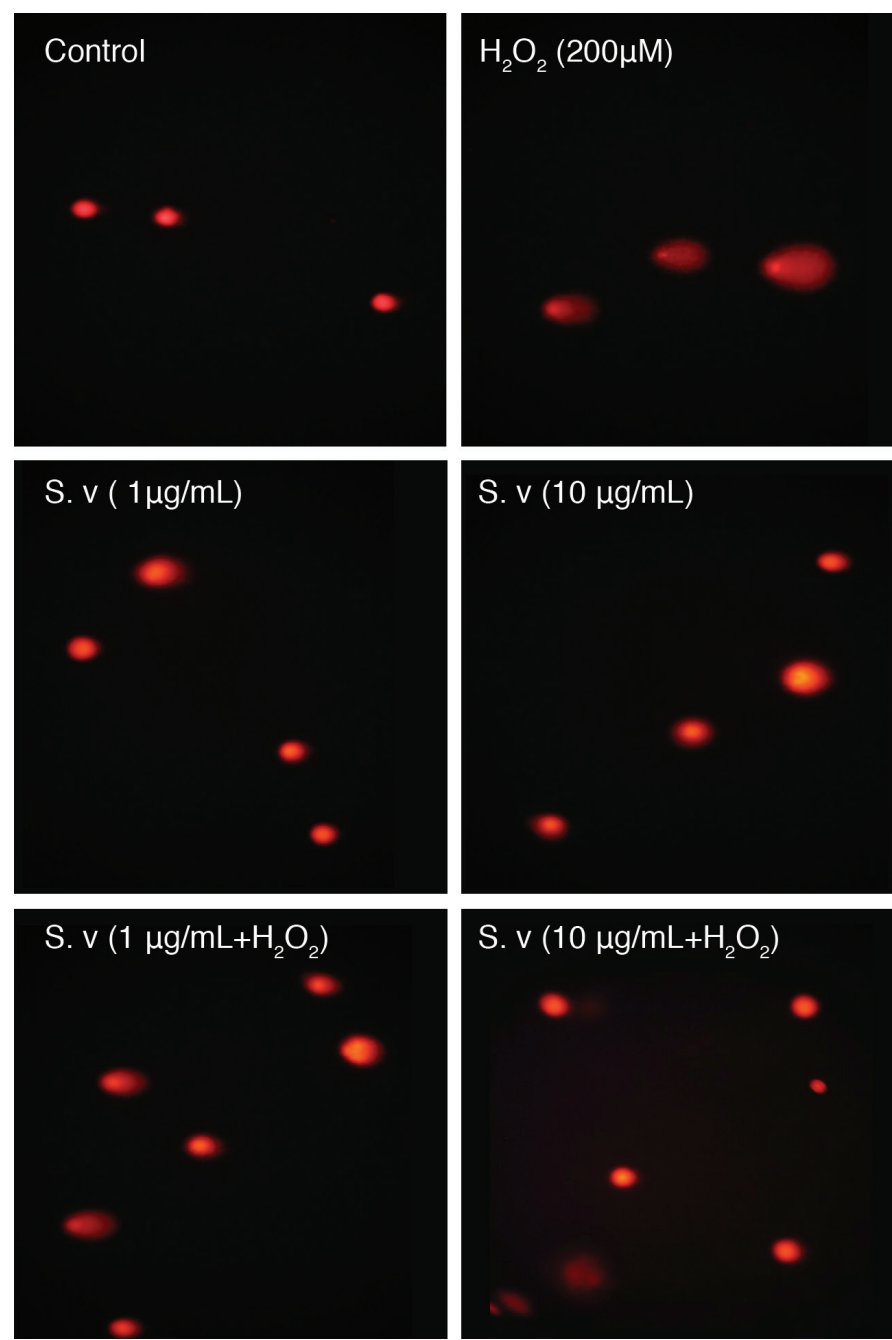

Figure 4. Fluorescence photomicrographs for DNA breakage in THP-1 cells studied using comet assay (original magnification 10x40). $\mathrm{H}_{2} \mathrm{O}_{2}$-treated cells exhibited high levels of DNA breakage (comet tail-like appearance), $S$. verbenaca-treated cells showed no DNA degradation (spherical mass), the cells treated with $\mathrm{H}_{2} \mathrm{O}_{2}$ and $\mathrm{S}$. verbenaca ( 1 and $10 \mu \mathrm{g} / \mathrm{mL}$ ) showedlow to very low levels of DNA breakage 
(NIH/3T3) using MTT assay. The use of methanol and ethyl acetate extracts for both species resulted in a significant doseand time-dependent increase intoxicity. However, the ethyl acetate extracts were found to be more cytotoxic.

Gateva et al. ${ }^{22}$ reported the cytotoxic effects of $S$. officinalis extract at the concentration of $100 \mu \mathrm{g} / \mathrm{mL}$ in Hordeum vulgare root meristematic cells ( $p<0.05$ ). Additionally, S. officinalis extract was shown to exert cytotoxic effect on human lymphocytes, especially at the concentrations of 50 and $100 \mu \mathrm{g} / \mathrm{mL}$ ( $p<0.01$ ). In vivo study conducted by Vujošević and Blagojević ${ }^{23}$ reported cytotoxic effects of $S$. officinalis extract, at the concentration of $100 \mu \mathrm{L} / \mathrm{kg}$, toward mammalian bone marrow.

The ability of $\mathrm{S}$. verbenaca extract to reduce $\mathrm{H}_{2} \mathrm{O}_{2}$-induced ROS generation was measured using H2DCFDA assay. $\mathrm{H}_{2} \mathrm{O}_{2}$ was used as a positive control. $\mathrm{H}_{2} \mathrm{O}_{2}$ is widely used as a model for ROS production. It generates hydroxyl radicals $\left({ }^{\circ} \mathrm{OH}\right)$ in the presence of transition metal ions. Generally, $\mathrm{H}_{2} \mathrm{O}_{2}$ is delivered endogenously via certain physiological processes during oxidative phosphorylation. ${ }^{24}$ It can enter the nucleus and interact with DNA. ${ }^{25}$ These radicals can attack the sugar residues present in the DNA backbone, prompting single strand breaks. Additionally, these radicals can change purines and pyrimidines to their hydroxyl derivatives, for example 8-hydroxyguanine. ${ }^{26}$

The present study showed that the treatment of the cells with S. verbenaca extract ( 1 and $10 \mu \mathrm{g} / \mathrm{mL}$ ) resulted in a significant reduction in the intracellular levels of ROS produced by $\mathrm{H}_{2} \mathrm{O}_{2}$ $(p<0.05)$. The protective effects of $S$. verbenaca $(1$ and $10 \mu \mathrm{g} /$ $\mathrm{mL}$ ) against ROS production were found to be similar both in the presence or absence of $\mathrm{H}_{2} \mathrm{O}_{2}$. For both concentrations, $\mathrm{S}$. verbenaca showed no cytotoxicity and promoted cell viability. The ability of $S$. verbenaca extract to reduce ROS production might be attributed to its antioxidant activity. In aprevious study, Nassar et al. ${ }^{27}$ reported the presence of high antioxidant activity in S. verbenaca even at low concentrations. Similar results were reported in several studies involving Salvia species. Chang et al. ${ }^{28}$ reported that the root extracts of S. miltiorrhiza of Salvia genus exhibited antiapoptotic and antioxidant effects. This root extract was endowed with cancer preventing properties. S. miltiorrhiza extract mediated reduction in ROS generation was achieved by inhibition of oxidases, decrease in superoxide production, inhibition of oxidative alteration of low-density lipoprotein, and promotion of mitochondrial oxidative stress. This was accompanied by an increase in the enzymatic activity of antioxidant enzymes, such as GSH peroxidase, MnSOD, and catalase. ${ }^{28}$

It has been previously shown that the use of sage induced an increase in the amount of antioxidant enzyme GSH in Caco2 and HepG2 cells. ${ }^{29,30}$ This antioxidant enzyme reduced ROS production and provided protection against $\mathrm{H}_{2} \mathrm{O}_{2}$-induced cytotoxicity in Caco-2 cells. ${ }^{29}$

Comet assay was used to measure $\mathrm{H}_{2} \mathrm{O}_{2}$ mediated DNA breakage in THP-1 cells. The assay also investigated the ability of $\mathrm{S}$. verbenaca extract to protect the cells against this $\mathrm{H}_{2} \mathrm{O}_{2}$ induced DNA breakage. The treatment of the cells with $\mathrm{H}_{2} \mathrm{O}_{2}$ for $24 \mathrm{~h}$ resulted in a significant increase in DNA breakage and THP-1 nuclei were found to be highly fragmented. In $\mathrm{H}_{2} \mathrm{O}_{2}$ treated cells, DNA fragmentation was indicated by the augmentation of tail length and \% DNA content in the comet tail as compared to the untreated cells. Interestingly, no DNA breakage was observed in the cells treated with the extract, both in the presence and absence of $\mathrm{H}_{2} \mathrm{O}_{2}$. All these results suggested that the extract was endowed with excellent ability to protect the cell nuclei against DNA breakage. The efficacy of the extract ( 1 and $10 \mu \mathrm{g} / \mathrm{mL}$ ) was indicated by a significant decrease in the tail length and \% DNA content in each nucleus ( $p<0.001)$. In addition to this, all cell nuclei were characterized by a nearly spherical shape having low breakage. These results were in concordance with the findings of Bani Hani and Bayachou. ${ }^{31}$ The study showed that the incubation of HEK293 cells with $100 \mu \mathrm{M} / \mathrm{L}$ of $\mathrm{H}_{2} \mathrm{O}_{2}$ for $3 \mathrm{~h}$ resulted in a significant increase in the intrinsic cellular DNA oxidation. However, the use of $100 \mu \mathrm{L}$ of $S$. fruticose extract in the presence of 100 $\mu \mathrm{M} / \mathrm{L}$ of $\mathrm{H}_{2} \mathrm{O}_{2}$ for $3 \mathrm{~h}$ resulted in a significant decrease in the intrinsic cellular DNA oxidation. These results suggested that $S$. fruticose extract might enhance the activity of DNA repair machinery.

Several in vitro studies have previously suggested that Salvia species are endowed with antimutagenic, antidiabetic, antiangiogenic, and gastroprotective properties. ${ }^{32-35}$

The major polyphenols found in Salvia species include rosmarinic acid, caffeic acid, carnosol, and carnosic acid. ${ }^{36}$ In another study, Fotovvat et al. ${ }^{37}$ reported the occurrence of five phenolic compounds (rosmarinic acid, salvianolic acid A, salvianolic acid B, carnosic acid, and caffeic acid) at different concentration in the roots of 41 populations of 27 Salvia species. However, rosmarinic and caffeic acids were found to be most abundant among these five compounds. Renzulli et al. ${ }^{38}$ reported that rosmarinic acid present insage offered cytoprotective effect against in vitro cell damage induced by ochratoxin A and aflatoxin B1. Rosmarinic acid in sageacted via inhibition of toxin-induced ROS production and DNA and protein synthesis. In vitro study conducted by Tumur et al. ${ }^{39}$ showed that rosmarinic acid could reduce the cell viability of HNSCC tumoral cell line. Rosmarinic acid regulated the proliferation of the cells by blocking the signaling pathway of epidermal growth factor and increased ROS levels. ${ }^{39}$ In another study, carnosic acid and carnosol were found to inhibit ROS production and secretion of human leukocyte elastase. In addition to this, both polyphenols could attenuate the generation of proinflammatory leukotrienes in intact PMNL. ${ }^{40}$

Currently, very limited information is available regarding the chemical composition of $S$. verbenaca roots and its biological activities.

\section{CONCLUSION}

In the present study, S. verbenaca root extract was found to exhibit protective activity against $\mathrm{H}_{2} \mathrm{O}_{2}$-induced oxidative damage. The treatment of THP-1 cells with 1 and $10 \mu \mathrm{g} / \mathrm{mL}$ of the extract resulted in amelioration of $\mathrm{H}_{2} \mathrm{O}_{2}$-induced cytotoxicity, ROS production, and DNA breakage. Since S. verbenaca belongs to 
the Lamiaceae family, the DNA protective effects of the extract could be attributed to its antioxidant activity. Additionally, the polyphenols present in this plant might further contribute to this protective ability. Future studies aimed at the identification of secondary metabolites present in S. verbenaca roots might provide better understanding regarding its protective ability.

\section{ACKNOWLEDGMENTS}

The authors are grateful to the MESRS, Algeria.

Conflicts of interest: No conflict of interest was declared by the authors. The authors alone are responsible for the content and writing of the paper.

\section{REFERENCES}

1. Hamidpour M, Hamidpour R, Hamidpour S, Shahlari M. Chemistry, pharmacology, and medicinal property of sage (Salvia) to prevent and cure illnesses such as obesity, diabetes, depression, dementia, lupus, autism, heart disease and cancer. J Tradit Complement Med. 2014;4:8288.

2. Walker JB, Sytsma KJ, Treutlein J, Wink M. Salvia (Lamiaceae) is not monophyletic: implications for the systematics, radiation, and ecological specializations of Salvia and tribe Mentheae. Am J Bot. 2004;91:11151125.

3. Abravesh Z, Rezaee MB, Ashrafi F. Antibacterial activity of essential oil of salvia officinalis L. Iran J Med Aromat Plants Res. 2005;20:457-468.

4. Esmaeili MA, Sonboli A. Antioxidant, free radical scavenging activities of Salvia brachyantha and its protective effect against oxidative cardiac cell injury. Food Chem Toxicol. 2010;48:846-853.

5. Tenore GC, Ciampaglia R, Arnold NA, Piozzi F, Napolitano F, Rigano D, Senatore F. Antimicrobial and antioxidant properties of the essential oil of Salvia lanigera from Cyprus. Food Chem Toxicol. 2011;49:238-243.

6. Quezel P, Santa S. Nouvelle Flore de l'Algérie et des Régions Désertiques Meridionales. ( $2^{\text {nd }}$ ed). Paris: CNRS; 1963.

7. Bonnier G. La grande flore en couleurs de Gaston Bonnier. Paris: Nouvelles Flores de Bonnier; 1990.

8. Djeridane M, Yousfi B, Nadjemi S, Maamri F, Djireb, Stocker P. Phenolic extracts from various Algerian plants asstrong inhibitors of porcine liver carboxylesterase A. J Enzyme Inhib Med Chem. 2006;21:719-726.

9. Beniston N, Beniston W. Fleurs d'Algérie. Algérie: Entreprise Nationale Du Livre Alger; 1984.

10. Lahsissene H, Kahouadji A, Tijane M, Hseini S. Catalogue des plantes médicinales utilisées dans la région de zaër (Maroc occidental). Lejeunia. 2009;186:4157-4184.

11. Papaharalambus CA, Griendling KK. Basic mechanisms of oxidative stress and reactive oxygen species in cardiovascular injury. Trends Cardiovascul Med. 2007;17:48-54.

12. Jia X, Han C, Chen J. Effect of tea on preneoplastic lesions and cell cycle regulators in rat liver. Cancer Epidemiol Biomarkers Prev. 2002;11:16631667.

13. Khan MR, Rizvi W, Khan GN, Khan RA, Shaheen S. Carbon tetrachloride induced nephrotoxicity in rat: Protective role of Digera muricata. J Ethnopharmacol. 2009;122:91-99.

14. Klaunig JE, Kamendulis LM, Hocevar BA. Oxidative stress and oxidative damage in carcinogenesis. Toxicol Pathol. 2010;38:96-109.
15. Winterbourn CC. Reconciling. The chemistry and biology of reactive oxygen species. Nat Chem Biol. 2008;4:278-286.

16. Boutard B, Bouillant ML, Chopin J, Lebreton P. [Isolation of isoscoparine (C-glucosyl-6 chrysoeriol) from Potamogeton natans L]. C R Acad Hebd Seances Acad Sci D. 1972;274:1099-1101.

17. Barreca D, Currò M, Bellocco E, Ficarra S, S, Laganà G, Tellone E, Giunta ML, Visalli G, Caccamo D, Galtieri A,lentile R. Neuroprotective effects of phloretin and its glycosylated derivative on rotenone-induced toxicity in human SH-SY5Y neuronal-like cells. Biofactors. 2017;43:549-557.

18. Lee ZW, Kwon SM, Kim SW, Yi SJ, Kim YM, Ha KS. Activation of in situ tissue transglutaminase by intracellular reactive oxygen species. Biochem Biophys Res Commun. 2003;305:633-640.

19. Di Pietro A, Visalli G, La Maestra S. Biomonitoring of DNA damage in peripheral blood lymphocytes of subjects with dental restorative fillings. Mutat Res. 2008;650:115-122.

20. Ostling $\mathrm{O}$, Johanson KJ. Micro-electrophoretic study of radiationinduced DNA damage in individual mammalian cells. Biochem Biophys Res Commun.1984;123:291-298.

21. Poyraz E, Çiftçi GA, Öztürk N. Phenolic Contents, in vitro Antioxidant and Cytotoxicity Activities of Salvia aethiopis L. and S. ceratophylla L. (Lamiaceae). Rec Nat Prod. 2017;11:345-355.

22. Gateva S, Jovtchev G, Stankov A, Gregan F. Salvia Extract Can Decrease DNA Damage Induced by Zeocin. Int J Pharma Med Biol Sci. 2015;4:1-10.

23. Vujošević M, Blagojević J. Antimutagenic effect of extracts from sage (Salvia officinalis) in mammalian system in vivo. Acta Vet Hung. 2004;52:439-443.

24. Boveris A. Mitochondrial production of superoxide radical andhydrogen peroxide. Adv Exp Med Biol. 1977;78:67-82.

25. Termini J. Hydro peroxide induced DNA Damage and mutation. Mutat Res. 2000;450:107-124

26. Wang $K$, Hong $Y J$, Huang $Z Q$. Protective effects of silybin on human umbilical vein endothelial cell injury induced by $\mathrm{H}_{2} \mathrm{O}_{2}$ in vitro. Vascul Pharmacol. 2005;43:198-206.

27. Nassar M, Zerizer S, Kabouche Z, Kabouche A,Bechkri S. Antioxidant and the immunomodulatory activity exhibited by three plants from Lamiaceae family. Int J Pharm Pharm Sci. 2015;7:331-334.

28. Chang CC, Chang YC, Hu WL, Hung YC. Oxidative stress and salvia miltiorrhiza in aging-associated cardiovascular diseases. Oxidative Med Cell Longev. 2016;2016:4797102.

29. Aherne SA, Kerry JP, O'Brien NM. Effects of plant extracts on antioxidant status and oxidant- induced stress in Caco-2 cells. Br J Nutr. 2007;97:321-328.

30. Lima CF, Valentao PC, Andrade PB, Seabra RM, Fernandes-Ferreira M, Pereira-Wilson C. Water and methanolic extracts of Salvia officinalis protect HepG2 cells from t-BHP induced oxidative damage. Chem Biol Interact. 2007;167:107-115.

31. Bani Hani S, Bayachou M. Salvia fruticos are duces intrinsic cellular and $\mathrm{H}_{2} \mathrm{O}_{2}$ induced DNA oxidation in HEK 293 cells; assessment using flow cytometry. Asian Pac J Trop Biomed. 2014;4:399-403.

32. Lima CF, Azevedo MF, Araujo R, Fernandes-Ferreira M, Pereira-Wilson C. Metformin-like effect of Salvia officinalis (common sage): is it useful in diabetes prevention. Br J Nut. 2006;96:326-333.

33. Mayer B, Baggio CH, Freitas CS. Gastroprotective constituents of Salvia officinalis L. Fitoterapia. 2009;80:421-426. 
34. Patenkovic A, Stamenkovic-Radak M, Banjanac T, Andjelkovic M. Antimutagenic effect of sage tea in the wing spot test of Drosophila melanogaster. Food Chem Toxicol. 2009;47:1180-1183.

35. Keshavarz M, Mostafaie A, Mansouri K, Bidmeshkipour A, Motlagh HRM, Parvaneh S. In vitro and ex vivo antiangiogenic activity of Salvia officinalis. Phytother Res. 2010;24:1526-1531.

36. Charles DJ. Antioxidant properties of spices, herbs and other source. New York, USA: Ed Frontier Natural Products; 2013.

37. Fotovvat M, Radjabian T, Azra Saboora A. HPLC Fingerprint of Important Phenolic Compounds in Some Salvia L. Species from Iran. Rec Nat Prod. 2018;13:37-49.

38. Renzulli C, Galvano F, Pierdomenico L, Speroni E, Guerra MC. Effects of rosmarinic acid against a flatoxin B1 and ochratoxin-A-induced cell damage in a human hepatoma cell line (Hep G2). J Appl Toxicol. 2004:24:289-296.

39. Tumur Z, Guerra C, Yanni P, Eltejaye A, Waer C, Alkam T, Henson BS. Rosmarinic acid inhibits cell growth and migration in head and neck squamous cell carcinoma cell lines by attenuating epidermal growth factor receptor signaling. J Cancer Sci Ther. 2015;7:367-374.

40. Poeckel D, Greiner C, Verhoff M, Rau O, Tausch L, Hornig C, Steinhilber D, Schubert-Zsilavecz M,Werz O. Carnosic acid and carnosol potently inhibit human 5-lipoxygenase and suppress pro-inflammatory responses of stimulated human polymorphonuclear leukocytes. Biochem Pharmacol. 2008;76:91-97. 